\title{
Stock Market Development and Economic Growth: Empirical Evidence from Sri Lanka
}

\author{
${ }^{1}$ Kengatharan L., ${ }^{2}$ Vanajah S. \\ ${ }^{1,2}$ Department of Financial Management, University of Jaffna, Sri Lanka \\ ${ }^{1}$ lingesiya@univ.jfn.ac.lk
}

\begin{abstract}
The financial markets have played a crucial role in the country's economic life for a long time. The objective of this study was to examine the empirical relationship between stock market development and economic growth in Sri Lanka. This study used annual time series data for the period from 1990 to 2018 which were collected from the annual reports of the Colombo Stock Exchange (CSE) and the Central Bank of Sri Lanka. The data were analyzed employing co-integration test, and vector error correction model (VECM). The results of VECM revealed that stock market capitalization, foreign direct investment, and inflation have a significant impact on economic growth, while turnover has not significantly influenced economic growth. The findings of the study have an important implication for the economic policymakers and government of Sri Lanka to enhance economic growth. Further, research can be extended by choosing more periods of data and choosing other indicators of stock market development indicated in previous studies.
\end{abstract}

Keywords: Economic Growth, Inflation, Sri Lanka., Stock Market Development

\section{Introduction}

The stock market is one of the most important sectors which contributes to the country's economic growth by playing an important role. Research studies indicate that growth in the stock market is closely linked to economic growth (e.g: Nwagu,2020; Herath, 2020). On the one hand, by providing individuals with additional financial tools that can meet their risk preferences and monetary needs, stock markets are expected to accelerate household wealth creation.

On the other hand, in economic development, capital markets play an even more important role. In particular, the stock market facilitates the efficient mobilization of savings into investment, thus generating economic growth. In other words, it helps to distribute the resources required for the economy's sustainable growth. It is in this context that the stock market acts as an economic growth barometer. The role of the stock exchange can be explained by raising capital for business, mobilizing servings for investment, promoting business growth, corporate governance, creating investment opportunities for small investors, raising government capital for development projects, and economic barometer.

In the long term, many significant positions are likely to be played by the stock market. Next, one of the most critical tasks of the stock market is spreading the risks of the long-term investment plans. Stock market growth would lead to lower stock capital costs, thus allowing investments to take place and stimulating growth. Second, by continuously tracking the stock prices of companies and enforcing a degree of control over investment actions, it can lead to more productive 
investment. Thirdly, the growth of the stock market by attracting international portfolio flows will help boost the distribution of funds that can be invested.

The CSE, which is also one of the South Asian Exchanges and provides a fully electronic trading platform, is the only stock exchange in Sri Lanka. It plays a key role in the economic environment through the mobilization of savings, the allocation of resources, the provision of business platforms, access to finance, the increase in foreign capital inflows and the facilitation of local privatization programs. The strong commitment of CSE to Sri Lanka's development activities is the cornerstone of its growth and development as a repository of resources for depositors and investors.

Investors spend more time in the market seeking opportunities to boost their profits. They do not realize that their market investment decisions and behaviors contribute collectively to the country's development. There is a complex relationship between stock markets and economic growth. This study, therefore, seeks to find out the relationship between the development of the stock market and Sri Lanka's economic growth.

Many studies have explored the links between the performance of the stock market and economic growth. It has been convenient to test the situations in the developing markets, with markets being sufficiently big to affect the economies. Although the situation in Sri Lanka may be different, the comparatively smaller size of the stock market may have only a minimal effect on the economic activity of the country.

As a result, realistic recommendations must be made, if necessary, by considering industries and segments of the economy that are affected by developments in the stock market. The role of stock market development in Sri Lanka's economic growth is not well researched.

This study based on its nature will fill the research gap in the field of stock market development and economic growth and will provide readers with an insight into the factors that play a role in economic growth in Sri Lanka. Therefore, the objective of the study is to evaluate the relationship between the stock market development and economic growth in Sri Lanka. Thus, the research question of the study is that: Does stock market development impact economic growth in Sri Lanka?

\section{Literature Review}

Several studies investigated the relationship between financial development and economic growth. More specifically, the number of studies conducted to examine the relationship between stock market development and economic growth of a particular country. In this way recently, Nwagu (2020) studied to investigate the impact of stock market development on real economic growth in Nigeria. In order to evaluate annual time series data on stock market growth indicators and real gross domestic product (GDP) from 1984 to 2018, the Johansen Cointegration and VECM was used. The findings indicate a long-term correlation between stock market growth and economic growth in Nigeria. 
Akinmade, Adedoyin, and Bekin (2020) attempt to empirically examine stock market manipulation and its impact on economic performance on the Nigerian Stock Exchange. The empirical investigation employs a large data collection of 186 actual cases of manipulation identified between 2002 and 2016 by the Nigerian Security and Exchange Commission. In order to understand how different manipulation methods, influence market measures and the Error Correction Model to determine their economic impact. Economic variables (such as GDP) ultimately react negatively to manipulative trading. This result is informative and urges the Securities and Exchange Commission to establish regulatory responses to prevent and prosecute deceptive trade practices or other actions.

Herath (2020) carried out a study to estimate the effect of the development of the stock market on Sri Lanka's economic growth. For the period from 1990 to 2018 , relevant data was obtained from the records of the CSE and the Central Bank of Sri Lanka. The Ordinary Least Square (OLS) regression model was used primarily to achieve the study objectives. The analysis uses the turnover ratio (TR) in assessing stock market liquidity and the market capitalization ratio (MCR) is estimated to determine the size of the stock market. The estimated OLS regression coefficients show that, without any time lag, the turnover ratio has a positive effect on Sri Lanka's gross domestic product. Nevertheless, the results of the study indicate that the market capitalization ratio has a positive impact on the time lag of the gross domestic product.

Hatemi (2019) studied the causal impact of stock market development on the economic growth of the United Arab Emirates (UAE). The findings of the study revealed that the financial sector has a positive causal impact on economic performance. Further, they have found that such an impact is prominent when markets are falling than rising. Hence, it can be said that the development of the stock market in the UAE can function as a successful tool for the development of the real sector of the economy.

Further, Perera and Madurapperuma (2018) tried to identify the impact of stock market development on economic growth in Sri Lanka for the period from 2000 to 2017. Market capitalization, stock total traded value, turnover ratio, and inflation were considered as independent variables and economic growth was considered as a dependent variable in this study. The findings of the study suggested that there is a positive relationship between an efficient stock market and economic growth in the short run and long run.

Ogbeide and Kanli (2018) conducted a study to examine the development of the stock market and economic growth in the five major emerging national economies: Brazil, Russia, India, China, and South Africa. They took quarterly time series data from 1994 to 2014 when they did this research. To test the relationship between the growth of the stock market, a fixed effect calculation was used. The results indicate that growth in the stock market has a major effect on economic growth. The study further shows that there has been a strong link between measures of stock market development and the economic growth of the BRICS. Therefore, it is suggested that the vulnerabilities of each BRICS member country should be taken as a policy 
priority and that the strategies needed to improve them should be rapidly adopted by their respective governments.

As per the study of Khyareh and Oskou (2015), the objective of this paper is to examine the relationship between the creation of the stock market and Iran's economic growth. The paper explores the short and long-term dynamics of the relationship using quarterly data from 1998Q1 to 2012Q4 and using time series methodologies, including Johansen's co-integration, Vector error correction model, and Granger causality testing procedures. As per the outcome of this study, the Johansen co-integration test suggested that variables are co-integrated, and the VECM showed that there is a long-term relationship. Furthermore, the granger causality test revealed two-way causality between the stock market and Iranian development.

Niranjala (2015) investigated the relationship between stock market development and economic growth in Sri Lanka. The study applied modern econometric techniques to identify important aspects of the long-term relationship between these variables from 1990-2013. The results of the study revealed that the stock market performance plays a major role in economic growth in Sri Lanka. Athapathu and Jeyasinghe (2012) examined the causal relationship between stock market performance and economic growth in Sri Lanka based on the time series data for the period from 1997 - 2008. Market capitalization ratio, liquidity ratio, and turnover ratio were considered as indicators of stock market performance on the assumption that these variables are positively associated with the ability to mobilize capital and diversity of risk. The findings of the study suggested that the stock market has an impact on the country's economic activity. They have suggested that well developed and large stock market has a large effect on economic growth than the smaller size of the market.

Jahfer and Inoue (2014) investigated the relationships between stock market development and economic growth in Sri Lanka using quarterly data over the period from 1996 to 2011. This study found that stock market development leads the economic growth in Sri Lanka. Therefore, the study suggested that efforts should be devoted to developing the stock market to increase economic growth. Owusu and Odhiambo (2014) conducted a study to evaluate the impacts of capital account liberalization on economic growth in Ghana. He has considered three proxies of stock market development, such as stock market capitalization, stock market traded value, and stock market turnover. The result of this study revealed that stock market development has not shown any significant effect on the economic growth in Ghana. Mia et al., (2014) investigated the relationship between stock market development and economic growth in the case of Bangladesh considering the period from 2000 to 2013. For the data analysis, the Unit root test, Co integration test, and Granger Causality Test, and Robust regression have been performed to investigate the relationship. The results of this study revealed that there is a long-run relationship between stock market development and economic growth in Bangladesh. But in the short run, the causality runs only one-way from stock market development to economic growth. 
Similarly, Vacu (2013) assessed the long-run association between stock market development and the growth of the South African economy, using quarterly timeseries data from 1990 first quarter to 2010 fourth quarter. He used market capitalization, turnover ratio, and all share indexes as proxies for the stock market and GDP as a proxy for economic growth. The research employed, Johansen cointegration test and found a long-run relationship existing between the variables in the study. The short run and long-run dynamics were also captured using the VECM. The stock market's effect on growth was found to be statistically weak. The Granger causality test revealed that causality ran from economic growth to the stock market.

Chizea (2012), investigated the stock market growth relationship in Nigeria. He used market capitalization ratio (stock market size) to GDP, traded shares value ratio to GDP, and turnover ratio (stock market liquidity) as proxies for stock market development. And real GDP per capita to proxy economic growth in Nigeria used time series data from 1980 to 2007. Used Multivariate vector autoregressive models (VAR) as well as VECM. Johansen co-integration test and granger causality tests were performed and the Findings the tests revealed that a short and a long-running relationship existed between stock market variables and growth. Bidirectional causality was established, stock markets granger causes economic growth in Nigeria, similarly, economic growth Granger causes stock market development in the country.

On the other hand, Tuchinda (2011) also investigated the causal relationship between the stock market and economic growth in Thailand. The study employed 4 proxies of economic growth, namely GDP at the current price, GDP per capita, Real GDP, and Real GDP per capita. The stock market was assessed by market capitalization and turnover by volume. The feedback from the co-integration test revealed that the variables in question had a long-run relationship, and this causality was running from the stock market to economic growth, especially in the nonagricultural sector, as per the granger causality test.

Even though, findings of the study on the relationship between stock market development and economic growth differ from time to time and country to country. The current study differs from the latest empirical study conducted in Sri Lanka by Herath (2020) that, the advanced time series data analysis has been carried out to answer the research question.

The following hypothesis has been formulated based on the empirical review related to this study:

H1: There is a significant relationship between stock market development and economic growth in Sri Lanka.

\section{Methodology}

Numerical values and time series data are used in this study and this study adopts a quantitative research methodology that is an effective approach for collecting the relevant data for evaluating and finding the results of the study as a mathematical value. For the analysis, the present study used time series data. 


\section{Data Collection}

The present study mainly focuses on time series data collected from secondary sources. The annual reports of the Central Bank of Sri Lanka, CSE, and Department of Census and Statistics, the websites of respective organizations, International Monetary Fund report, and data library published by CSE from 1990 to 2018 were the main sources of data for this study. There are 29 annual observations that have been included for each of the variables throughout the research. The reason for using secondary data is due to it is more reliable as obtaining quality data from different sources and time-saving. Economic growth was a dependent variable which was measured as growth in the Gross Domestic Product while stock market capitalization ratio, stock value traded ratio, and foreign direct investment ratio were used as independent variables to measure the stock market development and inflation was used as the control variable.

Variables and their measurements are given in table I below:

Table I: Variables and their measurements

\begin{tabular}{l|l}
\hline Variables & Measurements \\
\hline $\begin{array}{l}\text { Stock market capitalization ratio } \\
\text { MCAP) }\end{array}$ & $\frac{\text { MCAP }}{\text { Nominal GDP }} * 100$ \\
\hline Stock value traded ratio (TR) & $\frac{\text { Total Value Traded }}{\text { Nominal GDP }} * 100$ \\
\hline Foreign direct investment (FDI) & $\frac{\text { FDI }}{\text { Nominal GDP }} * 100$ \\
\hline Economic Growth (EG) & $\frac{\text { GDP of this year }- \text { GDP of last year }}{\text { GDP of last year }}$ \\
\hline Inflation (INL) & Consumer's price index \\
\hline
\end{tabular}

\section{Model Specification}

In this study the error correction model as suggested by Hendry (1995) has been used to investigate the relationship between stock market development and economic growth,

The general form of the VECM is as follows:

$$
\begin{aligned}
& \Delta X_{t}=\alpha_{0}+\lambda_{1} E C_{t-1}^{1}+\sum_{i=1}^{m} \alpha_{i} \Delta X_{t-i}+\sum_{j=1}^{n} \alpha_{j} \Delta Y_{t-j}+\varepsilon_{1 t} \\
& \Delta Y_{t}=\beta_{0}+\lambda_{2} E C_{t-1}^{2}+\sum_{i=1}^{m} \beta_{i} \Delta Y_{t-i}+\sum_{j=1}^{n} \beta_{j} \Delta X_{t-j}+\varepsilon_{2 t}
\end{aligned}
$$


Where:

$\mathrm{EC}_{\mathrm{t}-1}$ :is the error correction term lagged one period,

$\lambda$ is the short-run coefficient of the error correction term $(-1<\lambda<0)$,

and $\varepsilon$ is the white noise.

\section{Data analysis}

\section{Descriptive statistic of the variable}

Table II shows descriptive statistics of the dependent variable and independent variables in this study to investigate the empirical relationship between stock market development and economic growth in Sri Lanka for the period from 1990 to 2018.

Table II: Descriptive Statistics

\begin{tabular}{|c|c|c|c|c|c|}
\hline & $\mathrm{N}$ & Minimum & Maximum & Mean & Std.Deviation \\
\hline MCAP & 29 & 3.8900 & 39.5000 & 18.4391 & 9.5419 \\
\hline TR & 29 & 0.1700 & 10.060 & 2.5479 & 2.2278 \\
\hline FDI & 29 & 0.2300 & 2.8170 & 1.1759 & 0.5524 \\
\hline INL & 29 & 2.2370 & 21.4950 & 8.8815 & 4.3240 \\
\hline EG & 29 & 0.5500 & 25.5600 & 8.9597 & 6.0963 \\
\hline
\end{tabular}

Source: Survey data

Table II illustrates that the stock market capitalization ratio has a maximum value of 39.5 and it has a minimum value of 3.89 and a standard deviation of 9.5419 and it also has a mean value of 18.44. The stock value turnover ratio has a maximum value of 10.06 and it has a minimum value of 0.17 at the same time it has a mean value of 2.55 and a standard deviation of 2.228. FDI has a maximum value of 2.82 and it has a minimum value of 0.23 and a standard deviation of 0.552 and it also has a mean value of 1.78. Inflation has a maximum value of 21.495 and it has a minimum value of 2.24 and a standard deviation of 4.324 and it also has a mean value of 8.89. GDP has a maximum value of 25.56 and it has a minimum value of 0.55 and a standard deviation of 6.096 and it also has a mean value of 8.96.

\section{Unit Root Analysis}

Table III: Unit root analysis of variables

\begin{tabular}{|l|c|c|c|c|c|c|}
\hline \multirow{2}{*}{ Variable } & \multicolumn{3}{|c|}{ Level } & \multicolumn{3}{c|}{ 1st Level } \\
\cline { 2 - 7 } & $\begin{array}{c}\text { Test with } \\
\text { intercept }\end{array}$ & $\begin{array}{c}\text { Test with } \\
\text { trend and } \\
\text { intercept }\end{array}$ & $\begin{array}{c}\text { Lag } \\
\text { length }\end{array}$ & $\begin{array}{c}\text { Test with } \\
\text { intercept }\end{array}$ & $\begin{array}{c}\text { Test with trend } \\
\text { and intercept }\end{array}$ & $\begin{array}{c}\text { Lag } \\
\text { length }\end{array}$ \\
\hline EG & 6.5520 & -2.8397 & 4 & -0.1888 & $-2.9309 * *$ & 2 \\
\hline MCAP & 4.7067 & -1.6596 & 2 & 0.9485 & $-5.7232 * * *$ & 1 \\
\hline TR & 1.0697 & -2.6081 & 0 & 0.0767 & $-5.8164 * * *$ & 0 \\
\hline
\end{tabular}


International Journal of Accountancy (IJA)-Volume 1 Issue 1 - June 2021

\begin{tabular}{|l|c|c|c|c|c|c|}
\hline FDI & 1.7187 & $\begin{array}{c}- \\
6.5270 * * \\
*\end{array}$ & 1 & 0.0345 & $-6.5894 * * *$ & 1 \\
\hline INL & 4.8608 & $\begin{array}{c}4.1262 * * \\
*\end{array}$ & 0 & -0.9516 & $-4.9730 * * *$ & 1 \\
\hline
\end{tabular}

Source: Survey data

Notes: *,**,*** indicates significance at the $10 \%, 5 \%$ and $1 \%$ level respectively.

Augmented Dickey-Fuller (ADF) test was performed to check the stationary status of the data. Table III shows the unit root result of Economic Growth, at zero level difference P-value was 0.0677. At the zero-difference level, the variable EG was non-stationary at 5\% level of significance. Therefore, it was performed first level difference, and then P-value was 0.0509 . Therefore, the variable was stationary at first difference with the marginal level of significance. The number of lags was selected as automatic-based SIC.

The unit root result of Stock market capitalization ratio at zero level difference and the P-value was 0.4391. At the zero-difference level, the variable seemed to be nonstationary. Thus, it was conducted the first level difference and P-value was 0.0001. Therefore, at the first level difference variable was considered stationary. The number of lags was selected as automatic-based SIC.

Similarly, table III also shows the unit root result of Stock value traded ratio, at zero level difference and P-value was 0.1033. Therefore, at the zero-difference level, the variable was non-stationary. Again, it was employed the first level difference and the P-value was 0.0001. It was found that the variable was stationary on the first differencing.

The zero level and first difference unit root results of Foreign direct investment and inflation suggest that the variables are stationary. As an automatic-based SIC, the number of lags was chosen. As a result, at the first difference, all variables are treated as stationary, and the co-integration test is performed.

\section{Co-Integration Test using Johansen Model.}

The Johansen Co-Integration test results indicate that the null hypothesis (proposing no Co-integrated) should be rejected at the 5\% significant level. This supports the following of the existence of long-term growth and stock market development.

Table IV: Co-Integration Test using Johansen Model.

\begin{tabular}{|c|c|c|c|c|c|c|}
\hline \multirow{2}{*}{$\begin{array}{c}\text { Hypothesized } \\
\text { no. } \\
\text { of } C E(s)\end{array}$} & \multicolumn{3}{|c|}{ Trace test } & \multicolumn{3}{|c|}{ Maximum eigenvalue test } \\
\cline { 2 - 6 } & $\begin{array}{c}\text { Test } \\
\text { statistic }\end{array}$ & $\begin{array}{c}\text { Critical } \\
\text { value 5\% }\end{array}$ & Prob.** & $\begin{array}{c}\text { Test } \\
\text { Statistic }\end{array}$ & $\begin{array}{c}\text { Critical } \\
\text { value 5\% }\end{array}$ & Prob.** \\
\hline & \multicolumn{3}{|c|}{ MCAP TUNVR FDI INFLATION GDP } \\
\hline
\end{tabular}




\begin{tabular}{|l|l|l|l|l|l|l|}
\hline None $*$ & 147.5054 & 69.81889 & 0.0000 & 67.12869 & 33.87687 & 0.0000 \\
\hline At most 1 * & 80.37672 & 47.85613 & 0.0000 & 46.28360 & 27.58434 & 0.0001 \\
\hline At most 2 * & 34.09312 & 29.79707 & 0.0151 & 24.10270 & 21.13162 & 0.0185 \\
\hline At most 3 & 9.990421 & 15.49471 & 0.2815 & 6.107687 & 14.26460 & 0.5994 \\
\hline At most 4 * & 3.882734 & 3.841466 & 0.0488 & 3.882734 & 3.841466 & 0.0488 \\
\hline
\end{tabular}

Notes: *Denotes rejection of the hypothesis at the 0.05 level

**MacKinnon-Haug-Michelis (1999) p-values

Table IV shows that at most 1 should be rejected at the $5 \%$ significant level. Because at most $1, \mathrm{P}$ value (0.0001) is less than 0.05. And Trace statistic value (80.37672) is higher than the 0.05 level critical value (47.85613). And Maximum Eigen value test value (46.28360) is higher than the 0.05 level critical value (27.58434). Likewise, at most 21 should be rejected at the 5\% significant level. Because at most 2, P value (0.0185) is at the 5\% level of significance. And Trace statistic value (34.09312) is higher than the 0.05 level critical value (29.79707). And Maximum Eigen value test value (24.1027) is higher than the 0.05 level critical value (21.13162). At most 3 should be accepted at the 5\% significant level. Because at most $\mathrm{P}$ value $(0.2815)$ is not significant at $5 \%$. And Trace statistic value (9.990421) is less than the 0.05 level critical value (15.49471). And Maximum eigenvalue test value (6.107687) is less than the 0.05 level critical value (14.2646). Likewise, at most 4 should be rejected at the $5 \%$ significant level. Because at most $4, \mathrm{P}$ value $(0.0488)$ is at the $5 \%$ significance level. And Trace statistic value (3.882734) is higher than the 0.05 level critical value (3.841466). And Maximum eigenvalue test value (3.882734) is higher than the 0.05 level critical value (3.841466).

Given the results generated, the null hypothesis of co integration equation is rejected at the 5\% level. Hence it is concluded that a long-run relationship exists among the macroeconomic variables and economic growth.

\section{Vector Error Correction Model (VECM)}

The presence of co-integration between variables suggests a long-term relationship among the variables under consideration. Then, the VEC model can be applied. Since the deviation from long-run equilibrium is gradually resolved by a series of partial short-run changes, the co-integration term is known as the error correction term. The VECM's dynamic specification allows for the deletion of irrelevant variables while retaining the error correction word. The length of the error correction term indicates how easily some disequilibrium will adjust to a long-run equilibrium state.

The long-run relationship between economic growth, market capitalization, turnover, FDI, and inflation was examined with co integrating vector error 
correction model for Sri Lanka in the period 1990-2018 is displayed below as per the results presented in table $\mathrm{V}$.

Table V: Co integrating equation

\begin{tabular}{llll} 
Equation & Parms & Chi2 & p >chi2 \\
\hline _cel & 4 & 240.6116 & 0.0000
\end{tabular}

Johansen normalization restriction imposed.

\begin{tabular}{|l|l|l|l|l|l|l|}
\hline beta & Coef. & Std.Err & $Z$ & $P>Z$ & \multicolumn{2}{|l|}{ [95\% conf.Interval] } \\
\hline cel & & & & & & \\
\hline EG & 1 & & & & & \\
\hline MCAP & -.5353 & .0996 & -5.37 & 0.000 & -.7306 & -.3401 \\
\hline TR & .3616 & .4567 & 0.79 & 0.428 & -.5335 & 1.2567 \\
\hline FDI & -8.8686 & 1.6125 & -5.50 & 0.000 & -12.0292 & -5.7080 \\
\hline INL & -1.8958 & .1923 & -9.86 & 0.000 & -2.2729 & -1.5188 \\
\hline CCons & 27.2373 & & & & & \\
\hline
\end{tabular}

Source: Survey data

As per the results presented in table $\mathrm{V}$, it can be summarized that market capitalization has a significant $(\mathrm{p}<0.01)$ impact on economic growth. However, turnover has not shown any significant impact on economic growth. Even though, FDI and inflation have a significant impact on economic growth in this study. Therefore, the hypothesis of the study supported the results of the study that there is a significant relationship between stock market development and economic growth in terms of market capitalization and FDI. But turnover did not have any significant impact on economic growth in this study. Long run normalized co integration model can be re-parameterized as below:

$\mathrm{ECT}_{\mathrm{t}-1}=\left[1.000 \mathrm{EG}_{\mathrm{t}-1}+.5353 \mathrm{MCAP}_{\mathrm{t}-1}-3616 \mathrm{TR}_{\mathrm{t}-1}+8.8686 \mathrm{FDI}_{\mathrm{t}-1}+1.8958 \mathrm{INL}_{\mathrm{t}-1}-\right.$ $27.2323 \mathrm{c}]$

Diagnostics test

Table VI: Lagrange-multiplier test

\begin{tabular}{llll}
\hline lag & Chi2 & df & prob>chi2 \\
\hline 1 & 34.9945 & 25 & 0.0883 \\
2 & 34.2210 & 25 & 0.1033 \\
\hline
\end{tabular}

Source: Survey data

Lagrange multiplier test was performed to exam the autocorrelation among the variables. As per the results presented in table VI, probability values are more than 0.05 . It clearly says that there is no autocorrelation. 
Table VII: Jargue-Bera test

\begin{tabular}{llll}
\hline Equation & Chi2 & df & prob>chi2 \\
\hline D_EG & 1.229 & 2 & 0.5408 \\
D_MCAP & 0.970 & 2 & 0.6157 \\
D_TR & 3.703 & 2 & 0.1570 \\
D_FDI & 3.751 & 2 & 0.1533 \\
D_INL & 1.082 & 2 & 0.5822 \\
All & 10.735 & 10 & 0.3785 \\
\hline
\end{tabular}

Source: Survey data

Jargue-Bera test was carried out to check the normality issues of the variables and results of the test presented in Table VII. As per the results presented in table VII, there are no normality issues in this study.

\section{Conclusion and Recommendation}

This study investigates the empirical relationship between stock market development and economic growth. Market capitalization ratio, the stock traded turnover ratio, and foreign direct investment were considered as proxies for stock market development. Changes in GDP were considered economic growth. Inflation was considered as a control variable on the relationship between stock market development and economic growth. Data were collected from 1990 to 2018 from the Central Bank and CES's annual reports. Stationary of the data tested using ADF test. Johansen co-integration test and VECM were used to estimate the relationship between stock market development and economic growth. The results of VECM revealed that stock market capitalization, foreign direct investment and inflation have a significant impact on economic growth, while turnover has not significantly influenced economic growth.

The results support the theoretical prediction that stock market creation would play an active role in economic growth. The study, therefore, concludes that stock market development is driving economic growth in Sri Lanka and efforts should be devoted to developing the stock market. The findings of this study discuss some policy issues where policymakers in Sri Lanka could play an active role in promoting capital markets in Sri Lanka by eliminating impediments to stock markets, such as legal and regulatory obstacles and portfolio and dividend flow restrictions. 


\section{Appendix A}

Vector error correction estimates are presented in the table I,

Table: Vector Error Correction Estimates

Included observations: 26 after adjustments

Standard errors in ( ) \& t-statistics in [ ]

\begin{tabular}{lc}
\hline Cointegrating Eq: & CointEq1 \\
\hline \hline EG (-1) & 1.000000 \\
MCAP (-1) & -0.952561 \\
& $(0.05069)$ \\
& {$[-17.1039]$} \\
& 1.768369 \\
TR (-1) & $(0.26578)$ \\
& {$[6.65350]$} \\
& -6.493831 \\
FDI (-1) & $(1.20621)$ \\
& {$[-5.38365]$} \\
& -2.482131 \\
INL (-1) & $(0.13047)$ \\
& {$[-19.0250]$} \\
C & 33.69681
\end{tabular}

\begin{tabular}{lccccc}
\hline \hline Error Correction: & $\mathrm{D}(\mathrm{GDP})$ & $\mathrm{D}(\mathrm{MCAP})$ & $\mathrm{D}(\mathrm{TR})$ & $\mathrm{D}(\mathrm{FDI})$ & $\mathrm{D}(\mathrm{INL})$ \\
\hline \hline CointEq1 & -0.068316 & 1.367084 & 0.211766 & 0.028045 & 0.286208 \\
& $(0.51778)$ & $(0.40028)$ & $(0.13699)$ & $(0.05111)$ & $(0.23374)$ \\
& {$[-0.13194]$} & {$[3.41536]$} & {$[1.54587]$} & {$[0.54869]$} & {$[1.22447]$} \\
D (GDP (-1)) & -0.892057 & -1.049333 & -0.404386 & -0.052231 & -0.105846 \\
& $(0.57177)$ & $(0.44201)$ & $(0.15127)$ & $(0.05644)$ & $(0.25811)$ \\
& {$[-1.56016]$} & {$[-2.37398]$} & {$[-2.67322]$} & {$[-0.92539]$} & {$[-0.41008]$} \\
D (GDP (-2)) & -0.228774 & 0.062908 & 0.059644 & 0.048431 & 0.076470 \\
& $(0.37161)$ & $(0.28728)$ & $(0.09832)$ & $(0.03668)$ & $(0.16775)$ \\
& {$[-0.61563]$} & {$[0.21898]$} & {$[0.60666]$} & {$[1.32026]$} & {$[0.45585]$} \\
D (MCAP (-1)) & 0.202463 & 0.356375 & 0.002792 & -0.017644 & 0.378615 \\
& $(0.35618)$ & $(0.27535)$ & $(0.09423)$ & $(0.03516)$ & $(0.16079)$ \\
& {$[0.56843]$} & {$[1.29427]$} & {$[0.02963]$} & {$[-0.50183]$} & {$[2.35474]$} \\
D (MCAP (-2)) & 0.024044 & 0.447096 & 0.025402 & 0.022566 & 0.119715 \\
& $(0.43841)$ & $(0.33892)$ & $(0.11599)$ & $(0.04328)$ & $(0.19791)$ \\
& {$[0.05484]$} & {$[1.31920]$} & {$[0.21901]$} & {$[0.52143]$} & {$[0.60490]$} \\
D (TR (-1)) & 0.673350 & -0.226865 & 0.495979 & 0.097969 & -1.135171 \\
& $(1.26800)$ & $(0.98024)$ & $(0.33547)$ & $(0.12517)$ & $(0.57241)$ \\
& {$[0.53103]$} & {$[-0.23144]$} & {$[1.47845]$} & {$[0.78268]$} & {$[-1.98314]$} \\
D (TR (-2)) & -0.028392 & -3.284132 & -0.928007 & -0.143159 & 0.075180 \\
& $(1.51996)$ & $(1.17501)$ & $(0.40213)$ & $(0.15004)$ & $(0.68615)$
\end{tabular}




\begin{tabular}{lccccc} 
& {$[-0.01868]$} & {$[-2.79497]$} & {$[-2.30772]$} & {$[-0.95413]$} & {$[0.10957]$} \\
D (FDI (-1)) & -0.478142 & 4.390137 & 0.901731 & -0.211366 & 2.366439 \\
& $(3.33670)$ & $(2.57946)$ & $(0.88278)$ & $(0.32938)$ & $(1.50627)$ \\
& {$[-0.14330]$} & {$[1.70196]$} & {$[1.02146]$} & {$[-0.64171]$} & {$[1.57106]$} \\
D (FDI (-2)) & -1.864817 & 4.294082 & 0.623524 & -0.523347 & -1.059066 \\
& $(3.41978)$ & $(2.64369)$ & $(0.90476)$ & $(0.33758)$ & $(1.54378)$ \\
& {$[-0.54530]$} & {$[1.62428]$} & {$[0.68916]$} & {$[-1.55028]$} & {$[-0.68602]$} \\
D (INL (-1)) & 0.599606 & 1.500447 & 0.316873 & 0.136289 & 0.021493 \\
& $(0.80521)$ & $(0.62248)$ & $(0.21303)$ & $(0.07949)$ & $(0.36349)$ \\
& {$[0.74466]$} & {$[2.41045]$} & {$[1.48743]$} & {$[1.71464]$} & {$[0.05913]$} \\
D (INL (-2)) & 0.222944 & 1.301861 & 0.290855 & 0.015138 & -0.165933 \\
& $(0.63890)$ & $(0.49391)$ & $(0.16903)$ & $(0.06307)$ & $(0.28842)$ \\
C & {$[0.34895]$} & {$[2.63584]$} & {$[1.72070]$} & {$[0.24002]$} & {$[-0.57533]$} \\
& -0.355023 & 0.924351 & 0.180798 & 0.067082 & -0.683349 \\
& $(1.27136)$ & $(0.98283)$ & $(0.33636)$ & $(0.12550)$ & $(0.57392)$ \\
\hline \hline R-squared & {$[-0.27925]$} & {$[0.94050]$} & {$[0.53751]$} & {$[0.53452]$} & {$[-1.19066]$} \\
Adj. R-squared & 0.635511 & 0.668472 & 0.727335 & 0.629511 & 0.725603 \\
Sum sq. resids & 519.349126 & 0.407986 & 0.513099 & 0.338412 & 0.510005 \\
S.E. equation & 6.090839 & 4.708569 & 1.611442 & 0.601253 & 2.749565 \\
F-statistic & 2.219081 & 2.566250 & 3.395011 & 2.162532 & 3.365541 \\
Log likelihood & -75.82132 & -69.12888 & -41.25026 & -15.61768 & -55.14240 \\
Akaike AIC & 6.755486 & 6.240683 & 4.096174 & 2.124437 & 5.164800 \\
Schwarz SC & 7.336146 & 6.821343 & 4.676834 & 2.705097 & 5.745460 \\
Mean dependent & -0.261154 & 0.672192 & 0.065385 & 0.018885 & -0.273577 \\
S.D. dependent & 7.549681 & 6.119600 & 2.309374 & 0.739203 & 3.927970 \\
\hline
\end{tabular}

\section{References}

Akinmade, B., Adedoyin, F.F. and Bekun, F.V. (2020), "The impact of stock market manipulation on Nigeria's economic performance", Journal of Economic Structures, Vol.9, No.1, pp.1-28.

Athapattu, A.R. and Jayasinghe, P. (2010), "Stock market performance and economic growth: The case of Sri Lanka", Proceedings of International Conferences on Information and Business (pp. 83-92). Colombo, Sri Lanka: University of Colombo.

Chizea, J. (2012), "Stock market development and economic growth in Nigeria: A time series study for the period 1980-2007" (Doctoral dissertation, Northumbria University).

Hatemi J, A. (2019), "The causal impact of stock market development on economic development in the UAE: An asymmetric approach", International Economics, Vol.72, No.2, pp.171-184.

Hendry, D.F. (1995), Dynamic Econometrics, Oxford University Press, Oxford. 
Herath, H.M.S.P. (2020), "The impact of stock market development on economic growth of Sri Lanka", SSRG international journal of economics and management studies, Vol.7, No.6, pp.108-111.

Jahfer, A. and Inoue, T. (2014), "Financial development, foreign direct investment and economic growth in Sri Lanka", International Journal of Economic Policy in Emerging Economies, Vol.7, No.1, pp.77-93.

Khyareh, M. M. and Oskou, V. (2015). "The Effect of Stock Market on Economic Growth: The Case of Iran", International Journal of Academic Research in Economics and Management Sciences, Vol.4, No.4, pp.52-62.

Mia, A. H., Qamruzzaman, M. and Ara, L. A. (2014), "Stock market development and economic growth of Bangladesh-A causal analysis', Bangladesh Journal of MIS, Vo.6, No.2, pp.62-74.

Niranjala, S. J. U. (2015), "Stock market development and economic growth in Sri Lanka", Global Journal of Management and Business Research, Vol.15, No.8, pp.39-44.

Nwagu,E.C. (2020), "Research on the impact of stock market development on real economic growth in Nigeria", Saudi Journal of Economics and Finance, Vol.4, No.9,pp. 471-480.

Ogbeide, S. and Akanji, B. (2018), "Stock market development and economic growth of Brazil, Russia, India, China and South African (BRICS) Nations: An empirical research", Accounting, Vol..4, No.2, pp.83-92.

Owusu,E.L. and Odhiambo, E.M. (2014), "Financial liberalisation and economic growth in Nigeria: an ARDL-bounds testing approach", Journal of Economic Policy Reform,Vol.17, No.2, pp.164-177.

Perera, K.A.H. and Madurapperuma, M.W. (2018), "Stock market development and economic growth in Sri Lanka", 4th International Conference for Accounting Researchers and Educators, Department of Accountancy, Faculty of Commerce and Management Studies, University of Kelaniya, Sri Lanka. p52.

Vacu, N.P. (2013), "Impact of stock market development on economic growth: Evidence from South Africa" (Doctoral dissertation, University of Fort Hare). 